\title{
The Effect of Tillage Frequency and Weed Control on Yield of Tef (Eragrostis tef) in Yielmana-Densa Area, Northwestern Ethiopia
}

\author{
Alemayehu Assefa ${ }^{1}$, Minale Liben ${ }^{1}$, Tilahun Tadesse ${ }^{1}$ and Belsti Yeshalem ${ }^{1}$ \\ Adet Agricultural Research Center, P O Box 8, Bahir Dar, Ethiopia
}

\begin{abstract}
Tef is the major crop and has the highest share of grain production in Ethiopia. However, its productivity is limited to $896 \mathrm{~kg} / \mathrm{ha}$. An experiment was conducted on nitosols in the Yielmana-Densa area of northwestern Ethiopia in the main cropping seasons of 2002-2004. The objective of the experiment was to determine the optimum tillage frequency, time and weeding frequency for tef production in the Yielmana Densa area. The experiment was designed in a factorial split plot using tillage as a main plot and weeding as sub plot. The tillage consisted of four frequencies (seven plows, five plows, three plows and one plow + roundup) and the weeding consisted of four levels (no weeding, weeding once at tillering, weeding once at stem elongation and weeding twice at tillering and stem elongation stages of the crop). Grain yield increased linearly as tillage frequency increased. Twice weeding increased yield by $39 \%$ over un-weeded. The highest grain yield was obtained when seven times plow was combined with weeding twice which resulted in an increase of yield by $96 \%$ over the lowest yield treatment (one plow + roundup + un-weeded). However, three times plowing combined with hand weeding at tillering was found to be an economical practice with the highest marginal rate of return and net benefit. It is, therefore, recommended to small-scale farmers around Yielmana Densa as a way of promoting sustainable crop production with fewer unfavorable effects on the environment.
\end{abstract}

Keywords: Nitosols; Tef; Tillage; Weed

\section{Introduction}

Tef is the major staple cereal crop of Ethiopia and highly adapted to diverse agro-ecological zones, including conditions marginal to the production of most of the other crops (Hailu and Seyfu, 2001). Seyfu (1991) stated that Ethiopian farmers prefer to grow tef because of its multiple advantages, such as high market value, reduced post-harvest management cost, low risk crop and the straw provides better animal feed than other cereals. In the Amhara region tef contributes the highest share $(21 \%)$ of grain production compared to other crops. However, its productivity is limited to $896 \mathrm{~kg} / \mathrm{ha}$ (CSA, 2002). Because of the morphological nature of the crop, especially its short and delicate stem, small leaves and shallow fibrous root system, tef offers lower resistance to weeds. About 48 to $49 \%$ yield loss of tef had been reported due to weed competition in western Amhara (Rezene and Zerihun, 2001). Farmers around Adet mostly practise twice hand weeding for tef from 30 to 60 days after planting. Most surveys reported that hand weeding in tef remains one of the most expensive, time- and energy consuming practice under all growing conditions (Rezene and Zerihun, 2001). Seyfu (1997) reported that the small size of tef seed poses a problem during sowing and, indirectly, during weeding as farmers find it difficult to use mechanical weeding implements and are forced to either hand weed or use chemical herbicides.

Most of the farmers in northwestern Ethiopia practice fine tef seedbed preparation with an average seven times oxen plow (Aleligne, 1988). The reason for fine seedbed preparation is to create a weed-free environment and good crop germination. However, traditional tillage (excessive tillage) had an unfavorable effect on the environment due to accelerated soil erosion (Reddy, 2000) and also increased cost of production.
An experiment conducted at Debre Zeit Research Center, Ethiopia indicated that hand weeding once at early tillering or twice at early tillering and stem elongation stage depending on the degree of weed infestation of the crop was profitable (Seyfu, 1993). However, no single weed control method gives satisfactory results and, therefore, an experiment consisting of tillage frequency, time and frequency of hand weeding was conducted in the Yilmana Densa area to determine optimum tillage frequency, time and frequency of weeding for tef production in the locality.

\section{Materials and Methods}

The experiment was carried out on nitosol in representative farmers' fields in the Yilmana-Densa Adet area of northwestern Ethiopia in the main cropping seasons from 2002 to 2004 . Adet is located at $11^{0} 17^{\prime} \mathrm{N}$ and $37^{\circ} 43^{\prime} \mathrm{E}$, with an altitude of $2240 \mathrm{~m}$ above sea level (a.s.l.) The dominant soil type is nitosol, exhibiting clay, sand and silt contents of approximately 70, 10 and 20\% respectively. Based on climatic data recorded at the Adet site over the past 8 years (1997-2004), mean monthly maximum and minimum temperatures were 26.0 and $9.6^{\circ} \mathrm{C}$ respectively. The mean maximum temperature ranged from $22.4^{\circ} \mathrm{C}$ in August to $29.4^{\circ} \mathrm{C}$ in March while the mean minimum temperature ranged from $5.5^{\circ} \mathrm{C}$ in January to $12.2^{\circ} \mathrm{C}$ in August. The rainfall pattern of the area is essentially unimodal. The rainy period extends from May to October with a peak during July. Total annual precipitation is $1161 \mathrm{~mm}$ with $1067 \mathrm{~mm}$ falling during the May-October growing season.

The experiment was conducted in a total of four sites (1 site in 2002, 2 sites in 2003 and 1 site in 2004). It was designed in a factorial split plot using tillage as a main plot and weeding as a sub-plot with three replications. The tillage consisted of four frequencies (seven plows,

\footnotetext{
*Corresponding author. E-mail: alemayehuassefa03@yahoo.com
} 
five plows, three plows and one plow + roundup) and weeding consisted of four levels (no weeding, weeding once at tillering stage, weeding once at stem elongation and weeding twice at the tillering and stem elongation stages of the crop). The variety DZ-01-196 was used at seed rate of $30 \mathrm{~kg} \mathrm{ha}^{-1}$. The gross and net plot size were $6 \mathrm{~m} \times 3 \mathrm{~m}\left(18 \mathrm{~m}^{2}\right)$ and $5 \mathrm{~m} \times 2 \mathrm{~m}\left(10 \mathrm{~m}^{2}\right)$, respectively. The first plowing, for all plots except the untilled plot, was done immediately after the harvest of the precursor crop. The herbicide, roundup, was sprayed once at a rate of 3 $1 /$ ha on the untilled plot at about 10 days before the planting of tef. The first weeding, at the tillering stage of the crop, was done about one month after planting and the second weeding at stem elongation was done about one month after the first weeding. Weed count is taken twice; firstly for untilled plots at the time of the roundup spray and, secondly, for all plots at the tillering stage of the crop using a quadrant size of $50 \mathrm{~cm}$ X $50 \mathrm{~cm}$ at two randomly-selected spots in each plot. Plant height of five randomly-selected plants in each plot was measured and the average plant height was calculated. The straw yield was calculated by subtracting the grain yield from the total crop dry biomass of the net plot. The data collected was subjected to analysis of variance using MSTATC Statistical software. The mean grain yield data was adjusted 10\% lower and subjected to partial budget and sensitivity analysis (CIMMYT, 1988). The labor data for tillage and weeding and the herbicide cost were considered as variable costs for economic analysis. An average market price of tef grain during the experimental periods 2003 and 2004 of the three months (Dec. to Feb.) was used.

Total costs that varied for each treatment were calculated and treatments were ranked in order of ascending total variable cost (TVC). Dominance analysis was used to eliminate those treatments costing more but producing a lower net benefit than the next lowest cost treatment. The marginal rate of return (MRR) was calculated for each non-dominated treatment. Sensitivity analysis was made through the assumption that variable costs and tef grain prices increased and decreased, respectively by $20 \%$ (Table 1 ).
Table 1. The mean cost of inputs and price of tef grain during the experimental years in Adet area.

\begin{tabular}{lll}
\hline Cost/Price of input/output & $\begin{array}{l}\text { Current } \\
\text { situation }\end{array}$ & $\begin{array}{l}\text { Sensitivity } \\
\text { analysis }\end{array}$ \\
\hline Cost of weeding (Birr/man days) & 5.00 & 6.00 \\
Cost of plowing (Birr/ha) & 80.00 & 96.00 \\
Cost of herbicide (Birr/l). & 60.00 & 72.00 \\
Price of tef grain (Birr/kg) & 2.29 & 2.09 \\
\hline
\end{tabular}

\section{Results and Discussion}

Generally, low weed infestation was recorded during the experimental periods. Weeds emerged late and weed infestation at the time of herbicide spraying of the untilled plot was not as expected. However, the herbicide (roundup) totally destroyed the emerging weeds on that particular plot. Sixteen weed species were recorded on the untilled plot with a total number ranging from 926 to $1962 / \mathrm{m}^{2}$, depending on the experimental sites. Cyperus esculentus, Commelina subulata and Setaria pumila were the major weeds on the untilled plots at the time of presowing. The late emergence of weeds was due to inadequate precipitation in April and May of the experimental years compared to the previous years (Figure 1). Generally, the average annual precipitation during the experimental years was $1001.2 \mathrm{~mm}$ which is less than the previous 5 years' average annual precipitation of $1257.28 \mathrm{~mm}$. The low annual precipitation during the experimental years contributed to low weed infestation during the crop growing season. Twenty one weed species were recorded at the tillering stage of the crop with total weed population ranging from 685 for seven plows treatment to $802 / \mathrm{m}^{2}$ for one plow plus roundup treatment (Table 2). This suggests that frequent tillage decreased the weed population during the crop growing season through enhancing weed emergence at the time of pre-sowing and thereby reducing the weed seed bank in the soil. This is in line with the findings of Yeshanew et al. (1996). The increase in weed species from 16 at pre-sowing on the untilled plot to 21 at the tillering stage of the crop is due to the fact that tillage led to a higher number of weed species emerging than the notillage system.

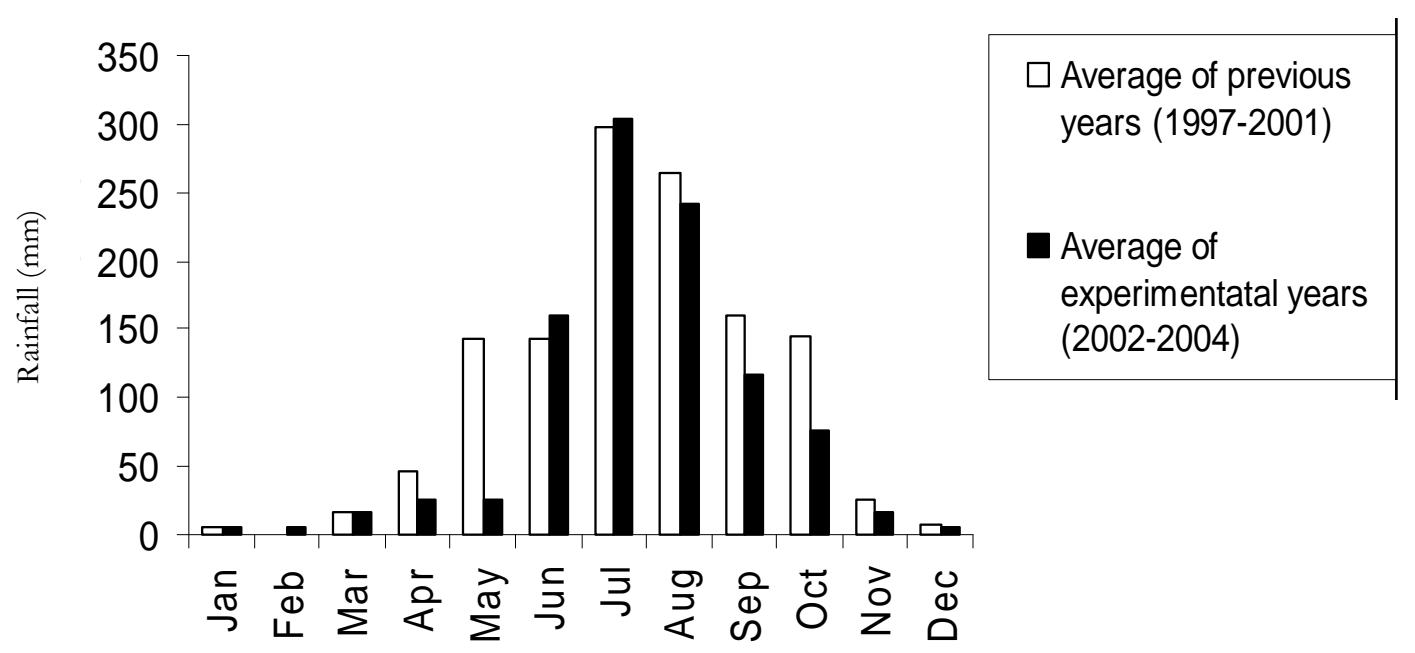

Figure 1. Monthly mean rainfall of the experimental years in relation to the previous years at Adet Agricultural Research Center 
Table 2. Counting of some major weed species (number $/ \mathrm{m}^{2}$ ) at the tillering stage of tef on the nitosol of YilmanaDensa, northwestern Ethiopia.

\begin{tabular}{llllll}
\hline \multirow{2}{*}{ Weed species } & \multicolumn{2}{l}{ Plowing frequency } & & & \\
\cline { 2 - 5 } & $\mathrm{P}_{7}$ & $\mathrm{P}_{5}$ & $\mathrm{P}_{3}$ & $\mathrm{P}_{1}+\mathrm{R}$ & Mean \\
\hline Corrigiola capensis & & 191 & 186 & 252 & 198 \\
Polygonum nepalence & 164 & 181 & 171 & 222 & 193 \\
Commelina sabulata & 69 & 68 & 66 & 79 & 71 \\
Cyperus esculentus & 58 & 68 & 84 & 31 & 60 \\
Setaria pumila & 50 & 56 & 65 & 31 & 51 \\
Erucastrum arabicum & 21 & 33 & 29 & 32 & 19 \\
Guizotia scabra & 23 & 16 & 15 & 22 & 115 \\
Other minor weeds & 102 & 119 & 104 & 133 & 802 \\
Total & 685 & 732 & 720 & & \\
\hline
\end{tabular}

$P_{7}=$ Seven plows, $P_{5}=$ Five plows, $P_{3}=$ Three plows, $P_{1}=$ One plow, $\mathrm{R}=$ roundup

Plant height and straw yield showed non significant responses to plowing frequency in almost all sites except site 3 for plant height and site 1 for straw yield (Table3). Grain yield response to plowing frequency was significant in site 1 and site 4 . All crop parameters showed significant responses to weeding and weeding by plowing frequency interaction in all the sites. The coefficient of variability of sub-plot and main plot varied between sites.

The combined analysis of plant height, grain and straw yield over sites (Table 4) indicated non-significant differences for sites by plowing frequency for all crop parameters. On the other hand, site-by-weeding interactions revealed significant differences in all of the crop parameters, showing variations in weed infestations among the sites. Grain and straw yield showed significant responses to plowing, weeding and their interactions whereas plant height showed significant responses only to weeding.

Table 3. Analysis of variance for individual sites on plant height, grain and straw yield of tef on nitosols in YilmanaDensa, northwestern Ethiopia.

\begin{tabular}{|c|c|c|c|c|c|c|c|c|c|c|c|c|}
\hline \multirow[t]{2}{*}{ Source } & \multicolumn{3}{|l|}{ Site 1} & \multicolumn{3}{|l|}{ Site 2} & \multicolumn{3}{|l|}{ Site 3} & \multicolumn{3}{|l|}{ Site 4} \\
\hline & $\begin{array}{l}\text { Plant } \\
\text { height } \\
(\mathrm{cm})\end{array}$ & $\begin{array}{l}\text { Grain } \\
\text { yield } \\
(\mathrm{kg} / \mathrm{ha})\end{array}$ & $\begin{array}{l}\text { Straw } \\
\text { yield } \\
(\mathrm{kg} / \mathrm{ha})\end{array}$ & $\begin{array}{l}\text { Plant } \\
\text { height } \\
(\mathrm{cm})\end{array}$ & $\begin{array}{l}\text { Grain } \\
\text { yield } \\
\text { (kg/ha) }\end{array}$ & $\begin{array}{l}\text { Straw } \\
\text { yield } \\
(\mathrm{kg} / \mathrm{ha})\end{array}$ & $\begin{array}{l}\text { Plant } \\
\text { height } \\
(\mathrm{cm})\end{array}$ & $\begin{array}{l}\text { Grain } \\
\text { yield } \\
(\mathrm{kg} / \mathrm{ha})\end{array}$ & $\begin{array}{l}\text { Straw } \\
\text { yield } \\
(\mathrm{kg} / \mathrm{ha})\end{array}$ & $\begin{array}{l}\text { Plant } \\
\text { height } \\
(\mathrm{cm})\end{array}$ & $\begin{array}{l}\text { Grain } \\
\text { yield } \\
(\mathrm{kg} / \mathrm{ha})\end{array}$ & $\begin{array}{l}\text { Straw } \\
\text { yield } \\
\text { (kg/ha) }\end{array}$ \\
\hline Plowing (P) & NS & $*$ & $*$ & NS & NS & NS & $*$ & NS & NS & NS & $*$ & NS \\
\hline Weeding (W) & * & $* *$ & $*$ & $* *$ & $* *$ & $* *$ & $* *$ & $* *$ & $* *$ & $* *$ & ** & ** \\
\hline $\mathrm{PxW}$ & $* *$ & $* *$ & $* *$ & $* *$ & ** & $* *$ & $* *$ & $* *$ & ** & * & ** & ** \\
\hline $\mathrm{CV}_{\%}$ (main plot) & 7.87 & 14.76 & 19.15 & 6.30 & 18.84 & 22.63 & 5.49 & 28.94 & 19.49 & 4.02 & 16.42 & 26.87 \\
\hline $\mathrm{CV}_{\%}$ (sub plot) & 3.59 & 5.47 & 11.00 & 4.92 & 11.18 & 16.13 & 4.39 & 17.07 & 11.81 & 5.34 & 11.23 & 11.46 \\
\hline
\end{tabular}

*, ** Significant at 5 and 1\% level of Probability, respectively

NS = Non-significant

Table 4. Combined analysis over sites on plant height, grain and straw yield of tef on nitosols in Yilmana-Densa, northwestern Ethiopia.

\begin{tabular}{|c|c|c|c|}
\hline $\begin{array}{l}\text { Source } \\
\text { of variation }\end{array}$ & Plant height $(\mathrm{cm})$ & $\begin{array}{l}\text { Grain yield } \\
(\mathrm{kg} / \mathrm{ha})\end{array}$ & $\begin{array}{l}\text { Straw yield } \\
(\mathrm{kg} / \mathrm{ha})\end{array}$ \\
\hline Plowing (P) & NS & $* *$ & $* *$ \\
\hline $\mathrm{PxS}$ & NS & NS & NS \\
\hline Weeding (W) & $*$ & $* *$ & $* *$ \\
\hline WxS & $* *$ & $* *$ & $* *$ \\
\hline $\mathrm{PxW}$ & NS & $* *$ & $*$ \\
\hline
\end{tabular}

The highest plant height was recorded in the plot of highest plowing frequency combined with un-weeded treatment (Table 5). This may be due to the fast vertical growth of the crop enabling it to successfully compete with weeds for light.

The highest and lowest grain yield of tef was obtained on the plots of highest and lowest plowing frequency respectively (Table 5). There was a linear increase in grain yield as plowing frequency increased which may be due to the increased competitive capacity of the crop with decreased weed population. Previous research results in different tef-growing areas of the country also indicated increased tef grain yield as plowing frequency increased (Fufa et al, 2001).A grain yield increase of $23 \%$ was recorded in the seven times plow over the one plow + roundup spray. In the case of weeding, the highest grain 
yield was obtained in plots with hand weeding twice at tillering and stem elongation and the lowest was in unweeded plots. Yield increase by $39 \%$ was recorded in plots weeded twice over un-weeded. Generally the highest grain yield $(1771 \mathrm{~kg} / \mathrm{ha})$ was obtained when seven times plow was combined with hand weeding twice at tillering and stem elongation. A yield increase of $96 \%$ was achieved over the lowest yield treatment (one plow + roundup + un-weeded).

Similarly, straw yield linearly increased as plowing frequency increased (Table 5). A sraw yield increase of 19 $\%$ was recorded in the seven times plow over the one plow + roundup spray. Unlike grain yield, the highest straw yield $(4723 \mathrm{~kg} / \mathrm{ha})$ was obtained when seven times plow was combined with un-weeded treatment. The highest straw yield in the un-weeded treatment compared to weeded treatments may be due to the inseparable mixtures of some weed plants with the total crop biomass at the time of harvesting.

An economic analysis on grain yield for the single factor effect is presented in Table 6. Seven times plow gave the highest net benefit (NB) compared to the other plowing frequencies. However, the marginal rate of return (MRR) for seven times plow was below the acceptable level. Weeding once at tillering gave the highest NB compared to the other weeding levels. Weeding at tillering had an acceptable level of MRR, both according to the current situation and sensitivity analysis. However, the economic analysis on grain yield for the interaction effect (Table 7) showed better NB and MRR than the single factor effect.
The highest NB was obtained when five times plow was combined with hand weeding at the tillering stage but the MRR was below the acceptable level. Since frequent plowing aggravates soil erosion (Reddy, 2000), low plow frequency with the highest MRR is advisable. Three times plow combined with hand weeding at tillering exhibited the highest MRR (343\%) and NB (birr $2470 \mathrm{ha}^{-1}$ ). The sensitivity analysis even in the worst economic situation is in line with the results of the current situation (Table 7). Previous research results did not show the necessity of plowing more than three times (Fufa et al, 2001).

\section{Conclusion}

Three times oxen plow combined with hand weeding at tillering was found to be the best choice to be recommended to small-scale farmers for tef production and also to promote sustainable crop production with fewer unfavorable effects on the environment. The plowing frequency should be performed in such a way that the first plow takes place immediately after the precursor crop has been harvested, the second plow takes place in June about a week before planting and the third plow takes place at the time of planting.

In seasons of high annual precipitation, a second weeding at stem elongation may be necessary depending on the intensity of weed infestation. Further research on tillage frequency in reference to vertisols and precursor crops is to be carried out in Yielmana Densa area. 
Table 5. Plant height, grain yield and straw yield of tef as affected by tillage frequency and weeding on nitosols in Yilmana Densa, northwestern Ethiopia.

\begin{tabular}{|c|c|c|c|c|c|c|c|c|c|c|c|c|c|c|c|}
\hline \multirow[t]{2}{*}{ Plowing frequency } & \multicolumn{5}{|c|}{ Plant height $(\mathrm{cm})$} & \multicolumn{5}{|c|}{ Grain yield $(\mathrm{kg} / \mathrm{ha})$} & \multicolumn{5}{|c|}{ Straw yield $(\mathrm{kg} / \mathrm{ha})$} \\
\hline & $\mathrm{W}_{0}$ & $\mathrm{~W}_{\mathrm{t}}$ & $\mathrm{W}_{\mathrm{S}}$ & $\mathrm{W}_{\mathrm{t}}+\mathrm{W}_{\mathrm{s}}$ & Mean & $\mathrm{W}_{0}$ & $\mathrm{~W}_{\mathrm{t}}$ & $\mathrm{W}_{\mathrm{s}}$ & $\mathrm{W}_{\mathrm{t}}+\mathrm{W}_{\mathrm{s}}$ & Mean & $\mathrm{W}_{0}$ & $\mathrm{~W}_{\mathrm{t}}$ & $\mathrm{W}_{\mathrm{s}}$ & $\mathrm{W}_{\mathrm{t}}+\mathrm{W}_{\mathrm{s}}$ & Mean \\
\hline $\mathrm{P}_{7}$ & 98.2 & 96.8 & 90.0 & 95.6 & 95.1 & 1394 & 1609 & 1475 & 1771 & 1562 & 4723 & 4583 & 3658 & 4279 & 4311 \\
\hline$P_{5}$ & 95.8 & 96.2 & 84.1 & 92.2 & 92.1 & 1226 & 1589 & 1269 & 1575 & 1415 & 4074 & 4445 & 2997 & 3850 & 3841 \\
\hline $\mathrm{P}_{3}$ & 96.4 & 94.3 & 87.9 & 93.2 & 92.9 & 1120 & 1441 & 1257 & 1557 & 1344 & 3880 & 4026 & 3110 & 3776 & 3698 \\
\hline $\mathrm{P}_{1}+$ roundup & 97.1 & 96.5 & 89.2 & 93.5 & 94.1 & 904 & 1439 & 1216 & 1528 & 1272 & 3513 & 4336 & 2917 & 3706 & 3618 \\
\hline \multirow[t]{2}{*}{ Mean } & 96.8 & 95.9 & 87.8 & 93.6 & & 1161 & 1519 & 1304 & 1608 & & 4047 & 4348 & 3171 & 3903 & \\
\hline & & $\mathrm{P}$ & W & PxW & & & $\mathrm{P}$ & $\mathrm{W}$ & $\mathrm{PxW}$ & & & $\mathrm{P}$ & W & $\mathrm{PxW}$ & \\
\hline $\mathrm{CV} \%$ & & 6.14 & 4.59 & 4.59 & & & 18.89 & 10.40 & 10.40 & & & 21.85 & 12.70 & 12.70 & \\
\hline $\mathrm{LSD}_{5 \%}$ & & NS & 2.4 & NS & & & 111 & 59 & 118 & & & 356 & 199 & 398 & \\
\hline
\end{tabular}

$P_{7}=$ Seven plows, $P_{5}=$ Five plows, $P_{3}=$ Three plows, $P_{1}=$ One plow, $R=$ roundup

$W_{0}=$ Unweeded, $W_{t}=$ Weeding at tillering, $W s=$ Weeding at stem elongation

Table 6. Economic analyses of plowing frequency and weeding on tef grain yield on nitosols in Yilmana Densa, northwestern Ethiopia.

\begin{tabular}{|c|c|c|c|c|c|c|c|c|c|c|}
\hline \multirow[b]{2}{*}{ Plowing frequency } & \multicolumn{4}{|c|}{ Current cost and price situation } & \multicolumn{3}{|c|}{ Current cost and price situation } & \multicolumn{3}{|c|}{ Variable costs and price of tef grain, increased and decreased, respectively by $20 \%$} \\
\hline & $\begin{array}{l}\text { TVC } \\
\text { (Birr/ha) }\end{array}$ & $\begin{array}{l}\text { Net Benefit } \\
\text { (Birr/ha) }\end{array}$ & $\begin{array}{l}\text { MRR } \\
(\%)\end{array}$ & Weeding & $\begin{array}{l}\text { TVC } \\
\text { (Brr/ha) }\end{array}$ & $\begin{array}{l}\text { Net Benefit } \\
\text { (Birr/ha) }\end{array}$ & $\begin{array}{c}\text { MRR } \\
(\%)\end{array}$ & TVC (Birr/ha) & Net Benefit (Birr/ha) & $\begin{array}{l}\text { MRR } \\
(\%)\end{array}$ \\
\hline $\mathrm{P}_{3}$ & 240 & 2530 & & $\mathrm{~W}_{0}$ & 0 & 2393 & & 0 & 2184 & \\
\hline $\mathrm{P}_{1}+$ roundup & 260 & $2362 \mathrm{D}$ & - & $\mathrm{W}_{\mathrm{t}}$ & 260 & 2871 & 184 & 312 & 2545 & 116 \\
\hline$P_{5}$ & 400 & $2516 \mathrm{D}$ & - & $\mathrm{W}_{\mathrm{s}}$ & 415 & $2273 \mathrm{D}$ & - & 498 & $1955 \mathrm{D}$ & - \\
\hline $\mathrm{P}_{7}$ & 560 & 2659 & 40 & $\mathrm{~W}_{\mathrm{t}} \mathrm{W}_{\mathrm{s}}$ & 490 & $2825 \mathrm{D}$ & - & 588 & $2437 \mathrm{D}$ & - \\
\hline
\end{tabular}

$P_{7}=$ Seven plow, $P_{5}=$ Five plow, $P_{3}=$ Three plow, $P_{1}=$ One plow, $\quad R=$ roundup

$W_{0}=$ Unweeded, $W_{t}=W_{\text {eeding }}$ at tillering, $W_{s}=$ Weeding at stem elongation

Table 7. Economic analysis of plowing frequency and weeding interaction on tef grain yield on nitosols in Yilmana-Densa area, northwestern Ethiopia.

\begin{tabular}{|c|c|c|c|c|c|c|}
\hline \multirow[b]{2}{*}{$\begin{array}{l}\text { Plowing frequency by } \\
\text { Weeding interactions }\end{array}$} & \multicolumn{3}{|l|}{ Current situation } & \multicolumn{3}{|c|}{ Scenario (if variable costs and price of tef grain, increased and decreased, respectively by $20 \%$ ) } \\
\hline & TVC (Birr/ha) & Net Benefit (Birr/ha) & MRR (\%) & TVC (Birr/ha) & Net Benefit (Birr/ha) & MRR (\%) \\
\hline $\mathrm{P}_{3} \mathrm{~W}_{0}$ & 240 & 2068 & & 288 & 1819 & \\
\hline $\mathrm{P}_{1} \mathrm{RW}_{0}$ & 260 & $1603 \mathrm{D}$ & & 312 & $1388 \mathrm{D}$ & \\
\hline $\mathrm{P}_{5} \mathrm{~W}_{0}$ & 400 & 2127 & 37 & 480 & 1826 & 4 \\
\hline $\mathrm{P}_{3} \mathrm{~W}_{\mathrm{t}}$ & 500 & 2470 & 343 & 600 & 2111 & 237 \\
\hline $\mathrm{P}_{1} \mathrm{RW}_{\mathrm{t}}$ & 520 & $2446 \mathrm{D}$ & & 624 & $2083 \mathrm{D}$ & \\
\hline $\mathrm{P}_{7} \mathrm{~W}_{0}$ & 560 & $2313 \mathrm{D}$ & & 672 & $1950 \mathrm{D}$ & \\
\hline $\mathrm{P}_{3} \mathrm{~W}_{\mathrm{s}}$ & 655 & $1936 \mathrm{D}$ & & 786 & $1578 \mathrm{D}$ & \\
\hline $\mathrm{P}_{5} \mathrm{~W}_{\mathrm{t}}$ & 660 & 2615 & 91 & 792 & 2197 & 45 \\
\hline $\mathrm{P}_{1} \mathrm{RW}_{\mathrm{s}}$ & 675 & $1831 \mathrm{D}$ & & 810 & $1477 \mathrm{D}$ & \\
\hline $\mathrm{P}_{3} \mathrm{~W}_{\mathrm{t}} \mathrm{W}_{\mathrm{s}}$ & 730 & $2479 \mathrm{D}$ & & 876 & $2053 \mathrm{D}$ & \\
\hline $\mathrm{P}_{1} R W_{t} W_{s}$ & 750 & $2399 \mathrm{D}$ & & 900 & $1974 \mathrm{D}$ & \\
\hline $\mathrm{P}_{5} \mathrm{~W}_{\mathrm{s}}$ & 815.0 & $1800 \mathrm{D}$ & & 978 & $1409 \mathrm{D}$ & \\
\hline $\mathrm{P}_{7} \mathrm{~W}_{\mathrm{t}}$ & 820.0 & $2496 \mathrm{D}$ & & 984 & $2043 \mathrm{D}$ & \\
\hline $\mathrm{P}_{5} \mathrm{~W}_{\mathrm{t}} \mathrm{W}_{\mathrm{s}}$ & 890.0 & $2354 \mathrm{D}$ & & 1068 & $1893 \mathrm{D}$ & \\
\hline $\mathrm{P}_{7} \mathrm{~W}_{\mathrm{s}}$ & 975.0 & $2065 \mathrm{D}$ & & 1170 & $1604 \mathrm{D}$ & \\
\hline $\mathrm{P}_{7} \mathrm{~W}_{\mathrm{t}} \mathrm{W}_{\mathrm{s}}$ & 1050.0 & $2600 \mathrm{D}$ & & 1260 & $2071 \mathrm{D}$ & \\
\hline
\end{tabular}

$D=$ dominated treatment,$\quad N B=$ net benefit,$\quad T V C=$ total variable costs, $\quad$ MRR = marginal rate of return

$P_{7}=$ Seven plows,$\quad P_{5}=$ Five plons, $\quad P_{3}=$ Three plows, $\quad P_{1}=$ One plow,$\quad R=$ roundup

$W_{0}=$ Unweeded,$\quad W_{t}=$ Weeding at tillering, $W_{s}=$ Weeding at stem elongation 


\section{Acknowledgment}

The authors acknowledge the technical staff of the Agronomy and Crop Physiology Research division of Adet Agricultural research Center for their assistance in the data collection throughout the experimental periods.

\section{References}

Aleligne, K. 1988. Diagnostic Survey Report of Adet Mixed Farming Zone. Research Report No. 4/88. IAR. Addis Ababa, Ethiopia.

CIMMYT (International Maize and Wheat Improvement Center). 1988. From Agronomic Data to Farmer Recommendations: An Economics Training Manual. Completely Revised Edition. CIMMYT. Mexico, D.F.

CSA (Central Statistical Authority). 2002. Crop Production Forecast Sample Survey 2002/03. Report on Forecast of Area and Production of Major Crops (For Rural Private Peasant Holdings). Statistical Bulletin No. 271. Addis Ababa, Ethiopia.

Fufa, H., Tesfa, B., Hailu, T., Kebebew, A., Tiruneh, K., Abera, D. and Seifu, K. 2001. Agronomy Research in Tef. In: Hailu, T., Getachew, B. and Mark, S. (eds.). Tef Research and Development. Proceedings of the International Workshop on Tef Genetics and Improvement. 16-19 October 2000. Debre Zeit, Ethiopia. pp. 167-176.

Hailu, T. and Seyfu, K. 2001. Production and Importance of Tef in Ethiopia Agriculture. In: Hailu, T., Getachew, B. and Mark, S. (eds.). Tef Research and Development. Proceedings of the International
Workshop on Tef Genetics and Improvement. 16-19 October 2000. Debre Zeit, Ethiopia. pp.3-7.

Reddy, S.R. 2000. Principles of crop production. $1^{\text {st }}$ edition. Kalyani publishers, New Delhi- 110 002, India.

Rezene, F. and Zerihun, T. 2001. Weed Research in Tef. In: Hailu, T., Getachew, B. and Mark, S. (eds.). Tef Research and Development. Proceedings of the International Workshop on Tef Genetics and Improvement. 16-19 October 2000. Debre Zeit, Ethiopia. pp. 201-213.

Seyfu, K. 1997. Tef Eragrostis tef (Zuuc.) Trotter. Promoting the Conservation and Use of Underutilized and Neglected Crops. Institute of Plant Genetics and Crop Plant Research. Gatersleben/International Plant Genetic Resources Institute. Rome, Italy.

Seyfu, K. 1993. Tef (Eragrostis tef) Breeding, Genetic Resources, Agronomy, Utilization and Role of Ethiopian Agriculture. IAR, Addis Ababa, Ethiopia.

Seyfu, K. 1991. Germplasm Evaluation and Breeding Work on Tef (Eragrostis tef) in Ethiopia. In: Engels, J.M.M., Hawkes, J.G. and Melaku, W. (eds.). Plant Genetic Resources of Ethiopia. Cambridge University Press. Cambridge. UK. pp. 323-328.

Yeshanew, A., Alemayehu, A. and Gowda, P.R. 1996. Preliminary Results of Weed Management Research in Barley Production Areas of North Western Ethiopia. In: Rezene, F. (eds.). Arem Vol.1. Proceedings of the First Annual Conference of the Ethiopian Weed Science Society. 24-25 Nov. 1993. Addis Ababa, Ethiopia. pp. 59-64. 